\title{
Teaching Feminist Economics. \\ Conceptual Notes and Practical Advice for Teaching a Subject in the Making
}

\author{
Anna Saave
}

\section{Abstract}

Teaching feminist economics is a relatively new didactical project posing questions of content and methodology for instructors. The article proposes three possible topics with regard to the changing nature of the emergent research field: introducing feminist economics as a mode of questioning, showing its historicity and spectrum, and asking the question of a unifying paradigm. Complementarily, the article identifies teaching methodologies and aspects to consider for teaching according to feminist economics' theoretical insights. This includes the role of experiences, the need for instructors to change perspectives, and the idea of caring and holding as starting points for a feminist pedagogy.

\section{Keywords}

Pedagogy $\cdot$ Feminist economics $\cdot$ Higher education $\cdot$ Teaching method $\cdot$ Gender

A. Saave $(\square)$

Friedrich Schiller Universität Jena, Jena, Deutschland

E-Mail: anna.saave@uni-jena.de 


\section{$1 \quad$ Teaching Feminist Economics? We Have a Situation. Context and Origin of the Need to Find Solutions for Teaching Feminist Economics}

When looking closely, we can identify feminist contributions throughout the history of economic thought, such as Harriet Taylor Mill's contribution to an economic understanding of the subjugation of women in the middle of the 19th century (Mill et al. 1976), Charlotte Perkins-Gilman's analysis of the marriage market (1980 [1898]), or Rosa Luxemburg's anti-imperialist political economy (1990 [1913]). However, feminist economics as an institutionalized field gained momentum only recently. With the foundation of the International Association for Feminist Economics (IAFFE) in 1992 and the first volume of the journal Feminist Economics published in 1995, feminist economics as an institutionalized economic sub-discipline is barely in her thirties. This community of scholars is built on historic progressive thinkers, but also on more recent discussions, like the wages for housework debate, the demand for the representation of social reproduction in national accounting, or debates about the understanding of the human being in economics (Ferber and Nelson 1993).

Consequentially, higher education on feminist economic topics has been scarce, if not non-existent. Only since 2016 a third professorship with a denomination in economics and gender has been appointed in Germany. However, its geographical and institutional location in the province at a university of applied sciences still reveals a lot about the institutional gatekeeping of the economics profession in Germany. Internationally, a number of professors are known for their work in feminist economics, but they are not institutionally marked with a denomination as professors of feminist economics, the chair of feminist economics at the University of Valencia being the exception.

Feminist economic research is produced by various people and institutions, but this is not equally reflected in higher education. IAFFE reacted to this issue by encouraging members to share course syllabi related to feminist economics on the IAFFE website in an effort to make teaching resources more accessible. The syllabi provided cover a wide range of topics, from 'women in the economy', 'gender and globalization' to 'statistics for feminists' and mostly date back to 2014/2015 (one course dating back to 1997). A textbook could help instructors, but there is no one standard feminist economics textbook. However, feminist economic scholarship has produced research that could possibly be used as a basis for higher education such as Beyond Economic Man: Feminist Theory and Economics (Ferber and Nelson 1993) or The Elgar Companion to Feminist 
Economics (Peterson and Lewis 1999) and the newly published Advanced Introduction to Feminist Economics (Jacobsen 2020). For the German speaking context, the edited volume Gender and Economics (Bauhardt and Çağlar 2010) provides a similar starting point. This shows that teaching feminist economics has been done, and can be done, but under barely institutionalized circumstances, and with a canon still under construction.

These historical and institutional circumstances require feminist economics courses to work towards building competences for entering a discourse. Moreover, they pose three major questions for educators who want to teach feminist economics: What can and should instructors in feminist economics teach without being able to rely on a canon? How can instructors teach feminist economics so that it is perceived as economically relevant despite not being anchored in mainstream economics departments? And how can it be taught given that students from diverse backgrounds and disciplines want to engage with feminist economics?

The teaching-learning-innovation required in the field of feminist economics is fundamental - teaching feminist economics is still an innovation in itself. To summarize the questions mentioned above, the innovation lies in: 1. providing guidance in the absence of a canon, 2. providing orientation and arguments why the field is necessary for a more inclusive economics, 3. making feminism, economics, and feminist economics accessible for an interdisciplinary group of students. A further challenge requiring teaching solutions is that teaching feminist economics has to reflect its variety of topics and methodologies, the various political positions of its authors, and the critique of the economic mainstream. All these aspects must to be reflected in an innovative teaching-learning-situation.

To approach these requirements and outline possible contents of a course on feminist economics, I want to briefly dive into the research in feminist economics to examine the following: (i) What is feminist economics and what did the people behind Feminist Economics want to change within the economics profession by introducing a journal dedicated to feminist debates? Additionally, I will (ii) show the spectrum of feminist economics today, including research published in Feminist Economics and beyond. Lastly, I will (iii) point out current trajectories and upcoming topics. By illustrating these aspects in this order, I will share with you how I provide guidance in the field (teaching requirement 1), and how I offer information showing the relevance of feminist economics for the future of economics (teaching requirement 2). Later, I will move to teaching related considerations and provide more information on my take of making feminist economics accessible (teaching requirement 3). In doing so I am relying on a teaching strategy similar to bell hooks" idea of creating a "democratic setting" (hooks 1994, p. 39). 


\section{Innovative Solutions in the Sense of a Plural, Socioeconomic Higher Education}

\subsection{Possible Contents of an Introductory Course on Feminist Economics}

\subsubsection{What Is and to What End Feminist Economics?}

Feminist economics is an academic field oriented towards "gender-aware and inclusive economic inquiry and policy analysis with the goal of enhancing the well-being of children, women, and men in local, national, and transnational communities." Thus, feminist economics pays special attention to social inequalities "based on gender or [...] other social categories such as race, ethnicity, sexual orientation [...]" (Miller 2013, p. 90). Complementary to this general definition, I use a categorization in class that helps identify three varieties of how economics can be feminist. This categorization gets students thinking about what might distinguish feminist economics from the economic mainstream and allows them to critically assess economic theory and the economics profession. Thereby, I introduce feminist economics as a mode of questioning. Drawing on the works of philosophy of science scholar Evelyn Fox Keller (1982), I call these: gender in economics, gender of economics and gendered economics. The first term, gender in economics, summarizes the question how gender as a concept is handled within economics. What understanding of gender is underlying economic theory? Does economic policy making systematically account for the fact that economic decisions affect different genders differently? The second term, gender of economics, summarizes the question who is part of economic theorizing and decision making. How many people in the economics faculty are female or identify as non-binary? Who gets to decide about macroeconomic programs that affect which populations in which ways? And the third term, gendered economics, refers to the fact that economic theorizing itself is not gender neutral. For example, Carolyn Merchant's (1982) critique of dualisms, which are a basis for Western philosophy and science, reveals that these - and economics - are gendered. Critically analyzing gendered economics thus reveals an androcentric bias regarding the Cartesian, epistemological basis of economics, complicates the notion of 'objectivity' and challenges the assumptions of human behavior explicit and implicit in the model of the 'rational

${ }^{1}$ IAFFE mission statement, Online: www.iaffe.org/pages/about-iaffe/miss/ [08.11.2019]. 
economic agent' (Ferber and Nelson 1993). Through these biases, economics is deeply gendered and contributes to a perpetuation of societal power relations along the lines of gender, racial, and other hierarchies.

In the first Feminist Economics article, Diana Strassmann (1995) covers all three varieties of this mode of questioning. Her entry point for explaining the necessity of the journal Feminist Economics is the culture of gatekeeping that so far prevented feminist research to be included in the economics canon. She criticizes the economic mainstream for ignoring the social construction of knowledge and reminds her readers that feminist economics as a sub-discipline should not become equally exclusive. The aspects of social construction of expert knowledge and authority, and gendered intersectional domination reproduced in the economics discipline are central underlying topics of feminist economics. I work with Strassmann's article to both show the historicity of feminist economics, which is a key teaching goal, and that her critique of gatekeeping raised almost 25 years ago is still appropriate.

\subsubsection{The Spectrum of Feminist Economics and What it Implies for Political Education}

Feminist economic scholarship has produced critical additions and objections to economic topics, and has established new fields of inquiry that might have been veiled by a "strategic silence" (Bakker 1994) before. A typical addition to the economic mainstream is the analysis of labor market participation of women or the return of mothers to the labor market after maternity leave. A typical objection to the economic mainstream is feminist criticism towards Gary S. Becker's (1981) New Home Economics which are relying just as much on sexist assumptions as on scientific scrutiny, as feminist scholars have fleshed out (Woolley 1996).

A key field of inquiry for feminist economics was always social reproduction and has become care work in the recent decades. Both topics center around activities traditionally done by women and people of color in many societies, but especially in Western capitalist societies. While social reproduction can refer to the reproduction of the social conditions of capitalist production, the reproduction of the labor force as well as biological reproduction (Edholm et al. 1978), I understand care work in a narrower sense as the caring activities for people who are not completely autonomous due to age, illness or a disability (Jochimsen 2003). Debates about social reproduction seek to clarify what role this plays in the overall reproduction of society and continued capitalist accumulation, whereas debates around care work highlight the specificities of care work versus other work. Both key concerns have been discussed on a spectrum reaching from 
an inclusion of house- and care work into the Marxian value theory of labor to an ethical theory of care work.

Concerning methodologies, researchers in feminist economics have placed far more emphasis on qualitative research than the formalized quantitative mainstream. As Haidinger and Knittler (2014, p. 89) point out: no single feminist question can be reduced to quantitative aspects alone. For the purpose of thinking about teaching feminist economics, it suffices to say that feminist economics critically complements findings of the economic mainstream, has been developing specific research agendas, and applies heterodox economic methodologies.

The spectrum of feminist economics today comprises all these academic endeavors and reaches politically from liberal to Marxist to ecological feminism. Keeping this spectrum in mind, instructors of feminist economics carry the responsibility to offer space and time to engage with different positions and building competence to enter this discourse. This is the basis for a pedagogy which allows students to understand feminist economics as a product of a comprehensive discourse and challenges students to position themselves in relation. Teaching the spectrum can also serve as a basis for keeping feminist economics open, countering potential gatekeeping tendencies.

\subsubsection{Does Feminist Economics Converge on a Single Paradigm? Current Trajectories in Feminist Economics}

As has already become clear, feminist economics is broad. Some contributions are paradigmatically rooted in the economic mainstream while others draw on critical insights of institutional economics. One sub-field uses a feminist-Marxist framework, while others adopt a post-development perspective. Judging from this variety, it would be simply false to assume that feminist economics is united by a common paradigm. However, a common denominator remains the critique of relations of power and domination affecting different genders differently as well as the ethical impetus to overcome these by providing economic research and policy proposals. I'd like to mention two approaches that might have the potential to become a theoretical paradigm for feminist economics: social reproduction theory and queer economies.

Social reproduction theory (Bhattacharya 2017) is a new theoretical paradigm stemming from debates among Marxist feminists. This field has recently converged towards the assumption of a unitary material social theory replacing the discussion about dual systems (i.e. capitalism + patriarchy) (Arruzza 2016). 
In the new synthesized framework, social reproduction is understood as a basis for capitalist accumulation next to the exploitation of the working class. Research on this topic has gained momentum so that I see a potential that paradigmatically undecided feminist economists might subscribe to it. However, this framework is currently defending itself against being accused as functionalist, determinist and reductionist (Arruzza 2016). Thus, only time will tell whether social reproduction theory becomes an own paradigm.

Another theoretical paradigm in feminist economics could develop via what Heiliger (2015) calls queer economies. From the position that gendered economics must be criticized and overcome (see 2.1.1), Heiliger proposes an entirely new understanding of the economic. This includes a concept of economic bodies driven by (queer) desires and enacted in clusters of economic activities. Her approach is informed by queer theory and actor network theory, pushing the boundaries of the economics discipline and challenging feminist economics as a sub-discipline.

As one possible new political paradigm I consider feminist approaches that practically think about creating community, nature, and (re)production in a postcapitalist setting. Keywords for this (relatively) new corpus of literature are feminist post-capitalist politics (Gibson-Graham 2006) and the various visionary approaches that conceptualize the economy as the center of social provisioning (Pérez Orozco 2014).

\subsubsection{Interim Conclusion}

The discussion of these aspects in the three subchapters above reveals what I think a course on feminist economics should cover: introducing feminist economics as a mode of questioning, presenting the spectrum of feminist economic inquiry alongside the variety of schools of economic thought and methodologies involved, and posing the question of a unifying paradigm with current trajectories of the field. Introducing feminist economics calls for a historical and cultural situating of the respective research and methodologies. "No one group possesses the theory or methodology that allows it to discover the absolute ,truth", as Hill Collins (1990, p. 234) reminds us. Taking this seriously implies that students must know that the research produced and methods applied with their differing underlying world views are competing and may even be mutually exclusive. I view it as an educational objective to make this spectrum accessible so that students see the necessity and possess resources to form their own position - one informed by feminist critiques of science, such 
as constructivism and standpoint epistemologies ${ }^{2}$. Both the diversity of economic thought and a critique of domination are inherent in feminist economics. This prompts the question of how feminist economics can be taught to reflect this diversity and critique (teaching requirement 3 ). In the following, I draw on the few existing works on teaching feminist economics and my personal experiences to provide you with didactical considerations on how to teach feminist economics.

\subsection{Considerations for Teaching Feminist Economics}

When designing my feminist economics courses to cover the aforementioned aspects, I could in theory have aimed at a classic , chalk and talk' style traditional for economics education (Becker and Watts 1996). However, feminist theory and activism calls for a renewal of teaching methodology which pays attention to social relations of power, voice and agency and also values different forms of knowledge and experience (Miller 2013). As the feminist-Marxist-antiracisteconomist Julie Matthaei says in her course syllabus on The Political Economy of Gender, Race and Class': "While I, as the professor, have, by necessity, set up the course structure and readings without consulting you, I welcome feedback and suggestions from students as to how to improve the course and make it more your own." Next to Matthaei's practical advice, a few proposals for pedagogy in feminist economics have been published. Miller (2013) proposes studentwritten diaries as a didactical tool to complement lectures, while Aerni et al. (1999) propose the classroom as a community of learners in contrast to a ,sageon-the-stage" setting. Both these innovations regarding media and social forms in the classroom serve as discussion points for developing didactics in feminist economics further.

My courses ${ }^{4}$ use a method mix of guided activities in groups or pairs, various media and material as well as lectures. A central entry point for me is to teach feminist economics as a mode of questioning (see 2.1.1). This equally refers to the content and method: Inviting students to critically engage with the material

\footnotetext{
${ }^{2}$ Feminist standpoint theory ,suggests that, knowledge is situated based on one's place in society“ (Miller 2013, p. 100).

${ }^{3}$ Provided Online: www.urpe.org/resource/course-syllabi/ [08.11.2019].

${ }^{4}$ Taught at Leuphana University Lüneburg and Cusanus Hochschule für Gesellschaftsgestaltung, both in Germany.
} 
offered is a generally good approach. I thereby seek to create a "democratic setting" (hooks 1994, p. 39). Maybe most importantly, I invite the students to contribute (in groups of 3-5) a short thematic impulse followed by an activity phase that involves all participants aimed at giving students the possibility to make the course their own.

An example of the methods and media I use concerns the beginning of the course. To start off, I encourage students to create an associations map. They're asked to imagine what they think feminist economics could be, and to find a definition of economics based on what we collected. This method is inclusive by incorporating the students ' existing knowledge and their imagination. I complement this by offering various approaches to finding such a definition including the ones proposed by the economic mainstream. In doing so, I aim at "unmasking of the false universality of neoclassical concepts" (Aerni et al. 1999, p. 33) as we go along.

In addition to these possible practical methods, I would like to highlight four meta-aspects which are relevant for the feminist economics classroom. With these pedagogical considerations I follow Aerni et al. (1999, p. 41) assuming that "changing how economics is taught will surely change economics"

\subsubsection{Experience Matters}

For all I know, feminist economics is perceived by most students as something exotic that requires explanation: Why should economics be feminist? In order to get students on board, I suggest to connect contents to their previous experiences in two ways, as also demanded by Lewis and McGoldrick (2002):

1. Many economics students have experienced the boundaries of the economics discipline as overly narrow. Students might have bumped against an invisible border when criticizing economic theory, or contributing insights from other disciplines. Bakker (1994) calls this a gendered strategic silence. The potentially shared feeling of 'voicelessness', of being unheard and misunderstood by fellow students and faculty can be a starting point for questions possibly answered through feminist economics.

2. As mentioned earlier, social reproduction and care work activities are key topics in feminist economics. All of us have personal experiences related to these activities. Often, these personal experiences are marked by gender or racial/ethnic discrimination that students can relate to on a personal level. It is important to show that feminist economics can provide answers to those potentially problematic experiences and prove that these are not necessarily private, but shared, economic or even public problems that need to be publicly addressed. 


\subsubsection{Teaching in a Feminist Way}

I mentioned post-capitalist politics and social provisioning as possibly emerging political paradigms in feminist economics. They often build on practices of commoning and especially advocate a commoning of care (Habermann 2016), including a redistribution and reorganization of care activities. I'm taking this demand to apply it to the teaching-learning-situation, thereby understanding the teaching practice as place of commoning of caring.

Commoning care requires to distribute the caring activities needed in the classroom and the responsibility for the shared learning process among all people participating in the teaching-learning-situation. This includes for example being respectful, actively supporting the learning process of others, contributing whenever possible or making an effort to communicate in class. Sharing the responsibility for these activities is possible even if one person provides the frame for the teaching-learning-situation. As Matthaei explained in her course syllabus (see quote above): all people participating can make the course their own.

Next to the distributive aspect, feminist scholars describe care in a qualitative way. In her article Holding hands at midnight, Folbre (1995) proposes holding as an inherent quality of caring activities. This is also applicable to teaching (feminist economics). Teaching, being part of the overall category of caring activities, can metaphorically incorporate the practice of holding: holding the space and time to make learning experiences. In a teaching-learning-situation, holding means staying present when students question prior opinions and explore new ones, and giving room even when students question hierarchies within the classroom. By allowing this, "students are encouraged to question the legitimacy of social hierarchies that they encounter elsewhere with respect to gender (and other social categories)" (Miller 2013, p. 98). However, allowing for such social forms can also create irritation as feminist economics is still embedded in a hierarchical academic context.

The need for room is especially relevant when students start speaking about feminist economics. To speak in the field of feminist economics has meant for most speakers to explain themselves and justify their approach to economics. It takes a lot to enter a conversation about feminist economics, i.e. to be critically informed about the economics canon and its shortcomings in order to be able to critically intervene in matters that seem to be self-evident in the economics profession. Acting as a critical commentator or to stand by a minority perspective on economics also requires practice. Therefore, a course on feminist economics should invite students to experiment with finding their voice and to let each other speak even if we stumble. Regarding media, student-written diaries may 
help to practice speaking: "As students write in their own voices, [...] they are empowered to add to the construction of the knowledge base within their classroom" (Miller 2013, p. 98). It may also help to discuss questions like "Who speaks? Who listens? And why?" (hooks 1994, p. 40). Thus, students can be primed for the need to be both informed and personally ready to enter the public discourse about feminist economics.

\subsubsection{Encouraging and Addressing Students' Questions}

What do students want to know? I systematically leave room for addressing this question. In my experience students regularly want to know if feminist economics has its own paradigm. From Kuhn, a paradigm is a closed set of rules or scientific assumptions that provide a tight frame for generating and evaluating scientific knowledge. Such a paradigm (found for example in neoclassical textbook economics) provides great security for students and might be appealing because through it the world becomes unambiguously interpretable. The hegemony of this paradigm and the security it offers can broadcast a certain superiority of mainstream economics and provide an anchor point for personal identification with a discipline like economics. Feminist economics has no such paradigm, as explained earlier, and can therefore not offer a paradigmatic ,home' like neoclassical economics can. However, it can provide another home. I encourage students to seek academic confidence through adopting a mode of questioning rather than a rigid paradigm. This is a methodological pedagogical consequence I derive from the state of feminist economics as a discipline.

Many students ask the big question: How can economics be different? The students I had the pleasure to meet so far broadly shared a concern for societal developments. Indeed, critical thinking and action is needed not only in the face of climate change. It is thus our responsibility as instructors of plural economics to use the knowledge treasures of our respective fields to show students which approaches, answers, and proposals have already been developed in the heterodoxy to do economics differently. This is especially relevant for feminist economics, as it has been devalued and excluded from the canon (Woolley 1996), not only because the field is plural, but also as it is concerned with seemingly 'private' or 'non-economic' topics. What is often a reason for its exclusion that it is done by women, that it is concerned with race, and that it uses methods that go beyond formalized or quantitative analysis - can now be a source of inspiration for a different economics.

After the first big question comes the next: How should the economy be like? Let's not be afraid to try to answer - that's where creativity comes in! Students always have opinions and proposals to do economics and the economy 
differently. They want to have a say, and a course on feminist economics offers a platform for their ideas. Also, feminist economics scholars have produced a considerable amount of proposals for alternative economies that students should be exposed to, like the commoning of care (Federici 2012), the proposal of an Ecommony (Habermann 2016), the (re)productive economy (Biesecker and Hofmeister 2010), or the sostenabilidad de la vida (sustainability of life) (Pérez Orozco 2014). Talking about these approaches opens doors for co-creating alternative economies, and economics.

However, answering these questions has never been done by economists alone. Activists and scholars from various fields contribute aspects that go far beyond traditionally perceived economically relevant knowledge. I encourage my students to allow experimental thinking, collect eclectically, to imagine possible futures and to own their imagination (e.g. within a world café or a "dream travel" exercise). This event in the teaching-learning-situation might appear to the reader as rather fanciful. However, instead of simply promoting wishful thinking, I consider it my duty to offer my students tools to engage with the economic future in a time where 'we', especially in the Global North, need guidance and courage to do things differently - fundamentally differently.

\subsubsection{A Change of Attitude}

To conclude the presentation of these meta-aspects, I'd like to add that teaching feminist economics, and creating space for feminist economics and economies, can require adopting a new attitude for students, but even more for instructors: "Once more, with feeling!," is how Julie Nelson (2003) calls others to join the project of renewing economics. But the demands of how to renew economics have changed. As mentioned earlier, the first article in Feminist Economics demanded that the economics profession gives up its ,gatekeeping. ' Twenty years later, Heiliger (2015) demands an intersectional, queer-feminist analysis and economic theory. Thus, feminist economists' demands have changed; currently, we can witness a partial return to Marxist theory and also a relatively collective learning progress triggered by Black Feminism (Hill Collins 1990). These important developments beg further clues regarding the innovation of teaching feminist economics: 1 . The historicity and developments in the field of feminist economics have to be fleshed out, 2. Inequality and power relations are no longer outside of economics nor are they going to be tolerated, 3. There is a need to actively look for concepts like intersectionality to be incorporated into economics.

I believe that when instructors of feminist economics embody and exemplify these three aspects, a lot is to be gained. This requires the courage and willingness of the people holding the teaching-learning-situation. It requires 
bodily commitment to be present, awareness of historicity and standpoint, and to expect to live and learn at any moment. It even requires instructors to sometimes "surrender their role of 'expert' and converse with students as intellectual equals" (Miller 2013, p. 98).

\section{Consequences and Effects of Teaching Feminist Economics in a Feminist Way and Conclusion}

The required teaching innovation for feminist economics is twofold, encompassing both the contents of an introductory feminist economics course as well as the methodological aspects of teaching economics in a feminist way. For evaluating the design of the introductory course on feminist economics regarding these aspects, I am using two available official teaching evaluation sheets from two universities. These suggest that students experience the atmosphere in the course as above average encouraging. Also, the students' evaluation scored exceptionally high in terms of students' motivation to autonomously further engage with the topics. Students specified that more than usual the lecturer as well as the students themselves contributed to a respectful atmosphere. This points towards a successful attempt to create a democratic setting.

Besides other aspects scoring high and being significant for a successful plural economics course, like interdisciplinary problem-solving and drawing connections to the students' previous knowledge, the evaluations also reveal challenges. While some students ask for a stronger lecture style, others wished for more discussions. This shows that a 'sage-on-the-stage' setting might for some still feel more familiar and appear as more effective. It also shows that lecturers have to offer various methodologies suitable for different learning styles. Reflecting on the course myself, I hope to allow even more in the future that students decide on the course topics. This flexibility however requires exceptional knowledge of the field and a number of teaching methodologies ready at hand in order to deliver the same standard of education as a highly structured course would.

To facilitate my own reflection process, I rely on a four-phase-model for making course content in economics more inclusive by Aerni et al. (1999). My efforts aim at overcoming the still prevailing standard to teach economics "as if gender is not relevant for understanding economic activity" (Aerni et al. 1999, p. 32). In contrast to this standard I choose teaching feminist economics as a mode of questioning, which corresponds to Aerni et al.'s request to challenge core concepts and propose alternatives. An economics course should not be 
exclusively about teaching students how to 'think like an economist.' Instead, it should demonstrate what is possible if we adopt notions of the economy, capitalist relations, work and the earth system that transcend the neoclassical boundaries of the economics discipline. Accordingly, the objective is to teach as inclusive, radical and controversial as possible. However, it will take plenty of such efforts in higher education to build "an economics that is redefined and reconstructed to include us all" (Aerni et al. 1999, p. 33). Yet, I choose to believe that the "classroom with all its limitations, remains a location of possibility" (hooks 1994, p. 207).

\section{References}

Aerni, A. L., Bartlett, R. L., Lewis, M., McGoldrick, K., \& Shackelford, J. (1999). Toward a feminist pedagogy in economics. Feminist Economics, 5, 29-44.

Arruzza, C. (2016). Functionalist, Determinist, Reductionist: Social Reproduction Feminism and its Critics. Science \& Society, 80, 9-30.

Bakker, I. (1994). The Strategic Silence. Gender and Economic Policy. London: Zed Books.

Bauhardt, C., \& Çaglar, G. (2010). Gender and Economics. Feministische Kritik der politischen Ökonomie. Wiesbaden: VS Verlag für Sozialwissenschaften.

Becker, G. S. (1981). A treatise on the family. Cambridge: Harvard University Press.

Becker, W. E., \& Watts, M. (1996). Chalk and Talk: A National Survey on Teaching Undergraduate Economics. American Economic Review, 86, 448-453.

Bhattacharya, T. (2017). Social Reproduction Theory. Remapping Class, Recentering Oppression. London: Pluto Press.

Biesecker, A., \& Hofmeister, S. (2010). Focus: (Re)productivity. Sustainable relations both between society and nature and between the genders. Ecological Economics, 69, 17031711.

Edholm, F., Harris, O., \& Young, K. (1978). Conceptualising Women. Critique of Anthropology, 3, 101-130.

Federici, S. (2012). Aufstand aus der Küche. Reproduktionsarbeit im globalen Kapitalismus und die unvollendete feministische Revolution. Münster: edition assemblage.

Ferber, M. A., \& Nelson, J. A. (1993). Beyond Economic Man. Feminist Theory and Economics. Chicago: University of Chicago Press.

Folbre, N. (1995). "Holding Hands at Midnight": The Paradox of Caring Labor. Feminist Economics, 1, 73-92.

Fox Keller, E. (1982). Feminism and science. Signs: Journal of Women in Culture and Society 7, 589-602.

Gibson-Graham, J. K. (2006). A Postcapitalist Politics. Minneapolis: University of Minnesota Press.

Habermann, F. (2016). Ecommony. UmCare zum Miteinander. Sulzbach am Taunus: Ulrike Helmer.

Haidinger, B., \& Knittler, K. (2014). Feministische Ökonomie. Wien: mandelbaum. 
Heiliger, E. (2015). Queer economies. Possibilities of queer desires and economic bodies (because "the economy" is not enough). In N. Dhawan, A. Engel, C. H. E. Holzhey, \& V. Woltersdorff (eds.), Global Justice and Desire: Queering Economy (S. 195-211). London and New York: Routledge.

Hill Collins, P. (1990). Black Feminist Thought. Knowledge, Consciousness, and the Politics of Empowerment. Boston: Unwin Hyman.

hooks, b. (1994). Teaching to Transgress: Education as the Practice of Freedom. New York: Routledge.

Jacobsen, J. P. (2020). Advanced Introduction to Feminist Economics. Cheltenham: Edward Elgar.

Jochimsen, M. A. (2003). Careful Economics: Integrating Caring Activities and Economic Science. Boston: Kluwer.

Lewis, M., \& McGoldrick, K. (2002). Moving Beyond the Masculine Neoclassical Classroom. Feminist Economics, 7, 91-103.

Luxemburg, R. (1990) [1913]. Die Akkumulation des Kapitals. Ein Beitrag zur ökonomischen Erklärung des Imperialismus. In Institut für Marxismus-Leninismus beim ZK der SED (Ed.), Gesammelte Werke Bd. 5. Ökonomische Schriften (S. 5-411). Berlin: Dietz Verlag.

Merchant, C. (1982). The Death of Nature: Women, Ecology and the Scientific Revolution. London: Wildwood House.

Mill, J. S., Taylor Mill, H., Taylor, H., \& Schröder, H. (1976). Die Hörigkeit der Frau und andere Schriften zur Frauenemanzipation. Frankfurt/M: Syndikat.

Miller, G. R. (2013). Teaching feminist economics through student-written diaries. Forum for Social Economics, 42, 88-112.

Nelson, J. A. (2003). Once More, With Feeling: Feminist Economics and the Ontological Question. Feminist Economics, 9, 109-118.

Pérez Orozco, A. (2014). Subversión feminista de la economía. Aportes para un debate sobre el conflicto capital-vida. Madrid: Traficantes de Sueños.

Perkins-Gilman, C. (1980) [1898]. Women and Economics. A Study of the Economic Relation Between Men and Women as a Factor in Social Evolution. New York: Source Book Press.

Peterson, J., \& Lewis, M. (1999). The Elgar Companion to Feminist Economics. Cheltenham: Edward Elgar.

Strassmann, D. (1995). Editorial: Creating a forum for feminist economic inquiry. Feminist Economics, 1, 1-5.

Woolley, F. (1996). Getting the better of Becker. Feminist Economics, 2, 114-120. 
Open Access Dieses Kapitel wird unter der Creative Commons Namensnennung 4.0 International Lizenz (http://creativecommons.org/licenses/by/4.0/deed.de) veröffentlicht, welche die Nutzung, Vervielfältigung, Bearbeitung, Verbreitung und Wiedergabe in jeglichem Medium und Format erlaubt, sofern Sie den/die ursprünglichen Autor(en) und die Quelle ordnungsgemäß nennen, einen Link zur Creative Commons Lizenz beifügen und angeben, ob Änderungen vorgenommen wurden.

Die in diesem Kapitel enthaltenen Bilder und sonstiges Drittmaterial unterliegen ebenfalls der genannten Creative Commons Lizenz, sofern sich aus der Abbildungslegende nichts anderes ergibt. Sofern das betreffende Material nicht unter der genannten Creative Commons Lizenz steht und die betreffende Handlung nicht nach gesetzlichen Vorschriften erlaubt ist, ist für die oben aufgeführten Weiterverwendungen des Materials die Einwilligung des jeweiligen Rechteinhabers einzuholen.

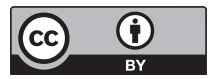

